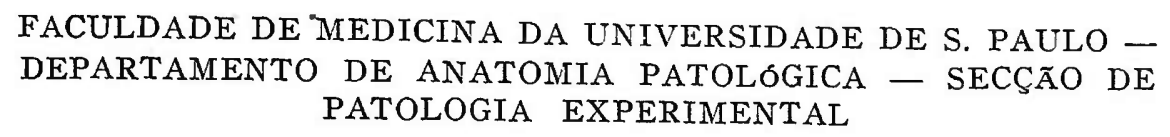

\title{
EXTRATOR PARA O ANDROGENO E O ESTROGENO URINARIOS
}

\author{
DR. J. LACAZ DE MORAES \\ Assistente
}

Quando trabalhavamos numa pesquiza sobre o androgeno urinário usamos de um rápido extrator descrito por Nathan B. Talbot e George O. Langstroth (Endocrinology, 25.729-1939), que apresentava uma grande vantagem sobre os aparelhos descritos por SмIтH e Smith (Amer. J. Physiol. 112.340-1935), o de Wang e Wu (Chinese J. Physiol., 8.209-1934), o de Gallagher, Кoch e Dorfman (Proc. Soc. Exper. Biol. \& Med., 33.440-1935) e sobre o descrito por W. V Conzolazio e J. H. Talbott (Endocrinology, 27:355-1940).

A grande vantagem era a agitação mecânica que permitindo um contato maior entre o benzol e a urina reduzia o tempo da operação para somente cerca de uma hora, conseguindo-se a extração de cerca de $90 \%$ dos hormonios urinários existentes num litro de urina.

Todavia pelo uso continuo do aparelho de TALBOT e LANGSTROTH um grave inconveniente apareceu. $\mathrm{O}$ eixo de vidro $\mathrm{CPG}$ Jena que permitia a agitação inferior de um modo eficiente, gastando-se deixava sair grande quantidade de urina o que prejudicava sobremodo a sequência do trabalho de extração.

Para resolver tal inconveniente foi que passamos a usar o apareTho que descreveremos, que com agitação pela parte superior, nos parece muito comodo e seguro pois evitou-se tambem o uso do fogo para a distilação continua do benzol, assim como o condensador.

\section{DESCRIÇÃO}

Consta o aparelho (fig. 1) de um balão de vidro de cerca de 1200 cc. de capacidade até o nivel de saida lateral. Lateralmente um funil separador provido de torneira a esmeril, por intermedio de um tubo de vidro recurvado, vem se abrir no fundo do balão numa pequena taça perfurada. Essa taça perfurada pode ser abolida pois o fim a que se destina de facilitar a emulsão perfeitał entre o benzol e a urina é conseguido somente pela agitação eficiente. 
No balão de vidro são colocados após resfriamento $1000 \mathrm{cc}$. de urina previamente hidrolisados com $150 \mathrm{cc}$. de $\mathrm{HCl}$ concentrado, pela fervura em 10 minutos. No funil separador conjunto ao aparelho são colocados $500 \mathrm{cc}$. ou mais de benzol cuja saida é regulada pela torneira e se òbtem a penetração de gotas de benżol no fundo do balão com uma velocidade tal que levará cerca de uma hora para seu total escoamento.

Um motor eletrico de indução de cerca de 2000 RPM ligado a um reostato para graduação da velocidade inicial e final e munido de eixo de vidrọ cuja extremidade livre tem duas pás de helice, permite a agitação comoda da urina e benzol.

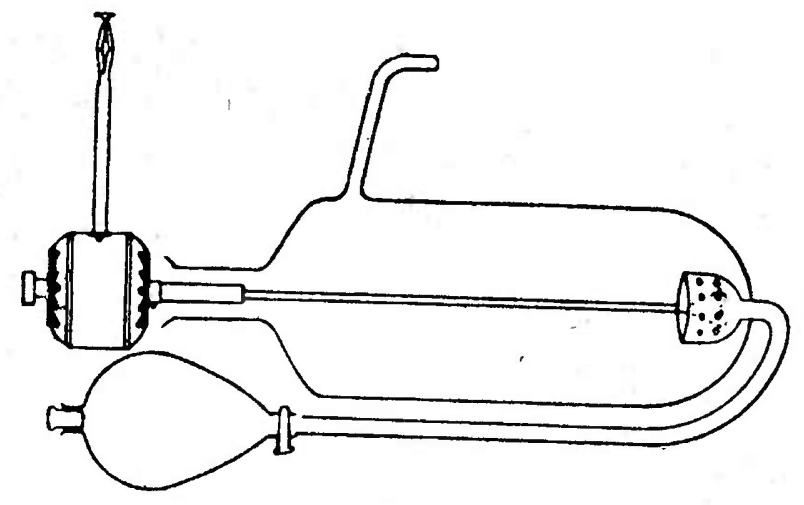

FIG. 1

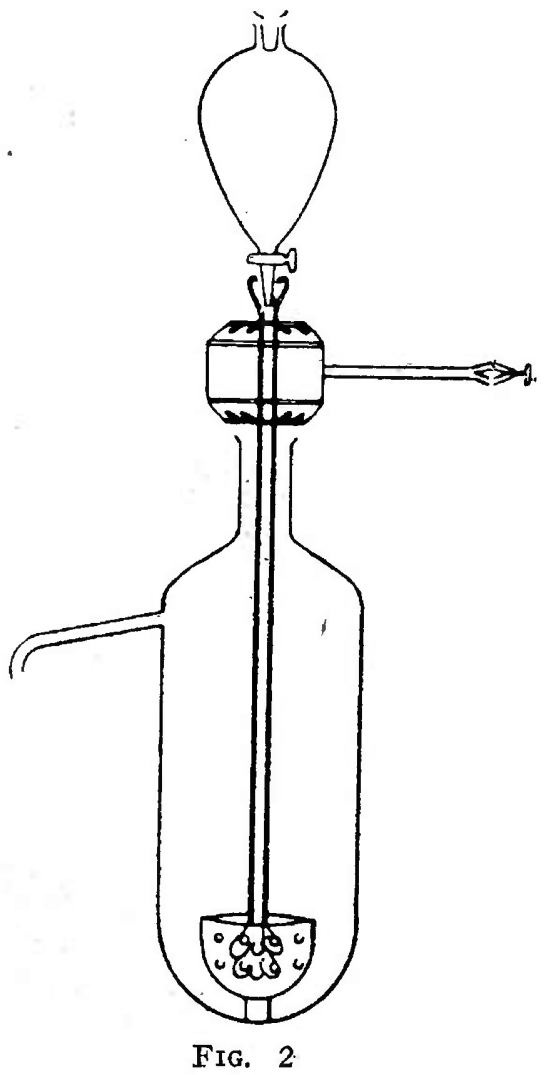

Esta agitação provoca a formação de uma emulsão que se escoa pelo tubo lateral e é recolhida num outro funil separador retiravel de cerca de 500 cc. que permite a separação. facil do benzol e da urina.

Este volume de benzol obtido é concentrado num alambique e o processo de extração se segue então nas fases descritas por TALBoT e LANGSTROTH.

Outra modificação que idealisavamos numa variante do aparelho (fig. 2) foi a de um motor que tem o eixo perfurado onde passa um tubo de vidro munido de uma helice numa das extremidades e noutra uma ampoula dilatada de bordos revirados para dentro, onde o benzol e um funil separador goteja em velocidade regulavel. 